\title{
Studi Analisis Penyelesaian Sengketa Merek melalui Singapore International Arbitration Centre (SIAC), World Intellectual Property Organizations (WIPO) Arbitration Centre dan Badan Arbitrase Nasional Indonesia (BANI)
}

\author{
Putra Pratama Mandiri Siregar ${ }^{1}$,Darminto Hartono
}

\begin{abstract}
Abstrak
Penyelesaian sengketa merek yang diatur dalam Undang-Undang No. 15 Tahun 2001 adalah melalui jalur pidana, perdata, arbitrase dan alternatif penyelesaian sengketa. Penyelesaian sengketa merek melalui arbitrase memiliki beberapa keunggulan dibandingkan melalui peradilan umum.. Selain peraturan prosedur arbitrase, terdapat perbedaan dalam pelaksanaan putusan asbritrase SIAC, WIPO Arbitration Centre dan BANI. Penelitian ini ingin mengkaji (1) penyelesaian sengketa merek melalui SIAC, WIPO Arbitration Centre dan BANI ditinjau dari peratuan prosedur arbitrase masing-masing, dan (2) pelaksanaan putusan SIAC, WIPO Arbitration Centre dan BANI ditinjau dari Undang-Undang No.30 Tahun 1999 tentang Arbitrase dan Alternatif Penyelesaian Sengketa dengan metode yuridis doktrinal. Berdasarkan penelitian ini SIAC merupakan badan arbitrase yang memiliki keunggulan dibandingkan badan arbitrase yang lain.
\end{abstract}

Kata-kunci : Penyelesaian Sengketa Merek, Pelaksanaan Putusan Arbitrase.

\begin{abstract}
Trademark dispute settlement set out in Act No. 15 of 2001 is through criminal, civil, arbitration and alternative dispute resolution. Trademark dispute resolution through arbitration has several advantages compared with common court. In addition to the rules of arbitration procedure, there are differences in the implementation of asbritrase SIAC decision, WIPO Arbitration Centre and the BANI. This study wants to examine (1) the settlement of trademark disputes by the SIAC arbitration, WIPO Arbitration Centre and in terms of legislation BANI arbitration procedure respectively, and (2) the implementation of the decision of SIAC, WIPO Arbitration Centre and BANI terms of Act 30 of 1999 on Arbitration and Alternative Dispute Resolution with doctrinal juridical methods. Based on this research SIAC an arbitration body that has advantages over other arbitration body.
\end{abstract}

Keywords : Trademark Dispute Resolution, Enforcement of Arbitration Awards.

\footnotetext{
${ }^{1}$ Mahasiswa Magister Ilmu Hukum Universitas Diponegoro

${ }^{2}$ Dosen Fakultas Hukum Universitas Diponegoro
} 


\section{A. Pendahuluan}

\section{Latar Belakang}

Pengaturan

tentang

penyelesaian sengketa dalam

undang-undang hak kekayaan

intelektual

adalah

diakomodasinya penyelesaian

sengketa melalui forum arbitrase

atau alternatif penyelesaian

sengketa. Undang-undang hak

kekayaan

intelektual

memberikan ruang dan

kebebasan bagi para pihak untuk

memilih forum penyelesaian

sengketa yang dinilai lebih

efektif, efisien dan solutif.

Forum arbitrase memiliki

karakteristik : (i) menjamin

kerahasiaan materi sengketa; (ii)

para pihak yang bersengketa

mempunyai kedaulatan untuk

menetapkan arbiter, tempat

prosedur beracara, dan materi hukum, (iii) melibatkan pakar-

pakar (arbiter) yang ahli dalam

bidangnya; (iv) prosedurnya

sederhana dan cepat; dan (v)

putusan forum tersebut

merupakan putusan terakhir

serta mengikat (final and

binding). ${ }^{3}$ Selain itu kelebihan

dari penyelesaian sengketa

melalui forum arbitrase adalah

kerahasiaan (confidentiality) dari

putusan yang dihasilkan.

Indonesia memiliki badan

arbitrase yang secara khusus

diberikan kewenangan untuk

3 Berbeda dengan asas yang dianut oleh pengadilan dalam memutus sengketa, yakni pemeriksaan perkara dan pembacaan putusan dilakukan dalam sidang yang terbuka untuk umum, sedangkan pemeriksaan yang dianut oleh forum arbitrase (arbitration institution) menganut asas pintu tertutup, sehingga ICSID (International Centre for Settlement of Investment Disputes) sebagai Badan Arbitrase Bank Dunia di dalam Rules of Procedure for Arbitration Proceedings (Arbitration Rules) pasal 48 ayat (4) menentukan : "The Centre shall nit publish the award without the consent of parties. The centre may, however, include in its publication excerpts of the legal rules applied by the Tribunal." Baca ICSID Basic Documents, Washington DC, 1985, h. 83. 


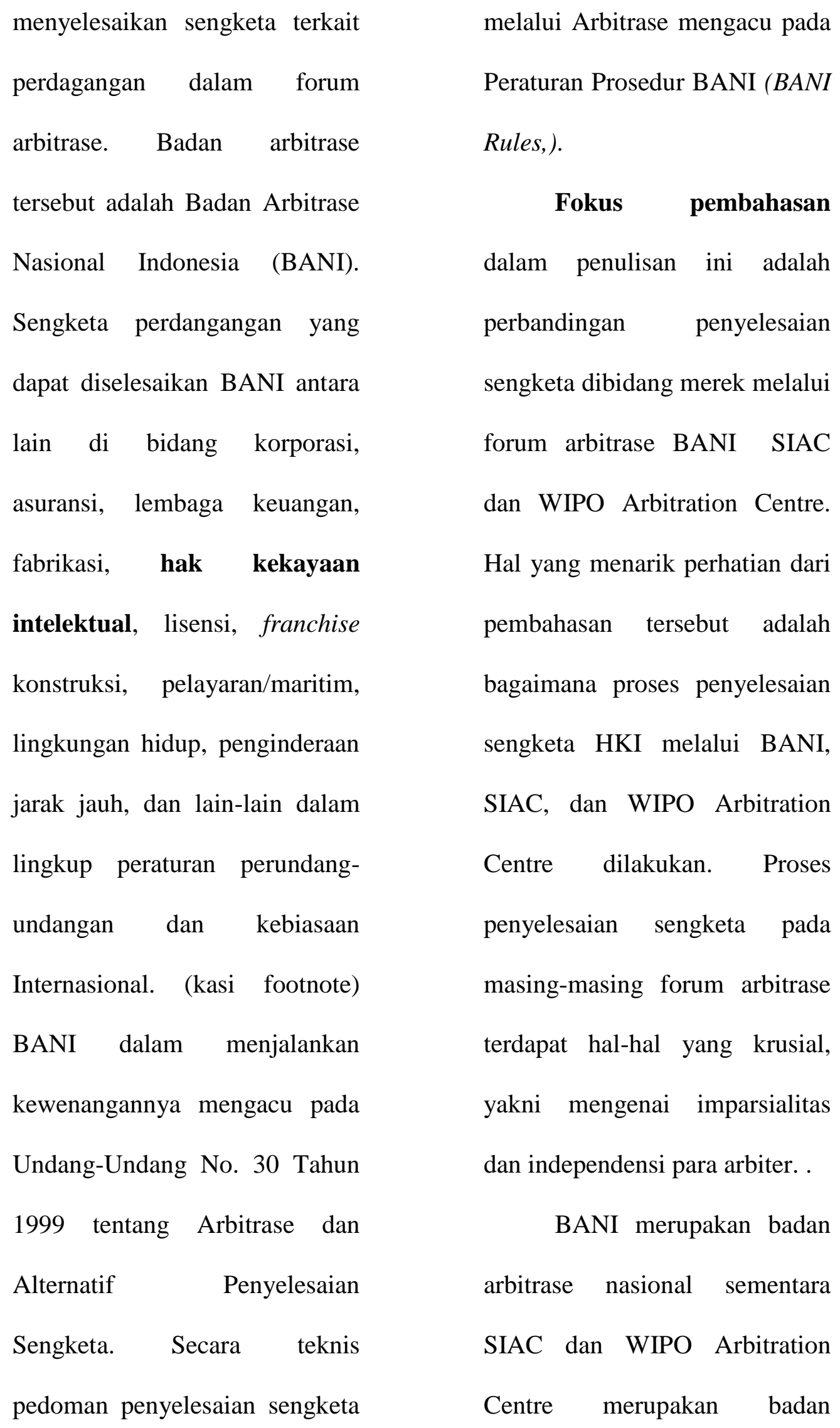




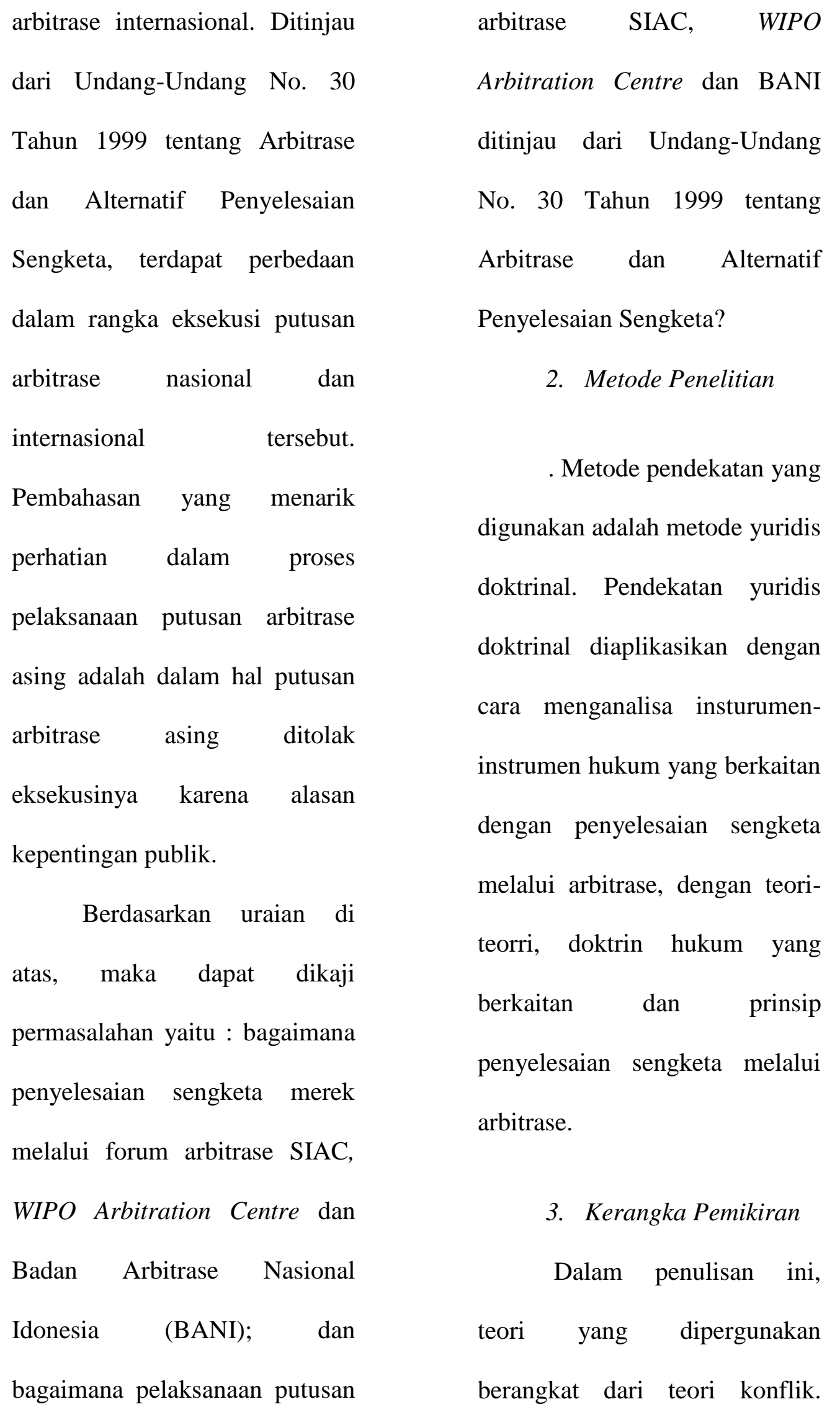


Menurut L.M Friedman, ada dua macam konflik, yaitu : conflict of interest dan claims of right. ${ }^{4}$ Selain teori Friedman di atas, penulis akan menggunakan teori perjanjian sebagai pisau analisis pembahasan. Purwahid Patrik mendefinisikan perikatan sebagai suatu hubungan hukum dalam lapangan harta kekayaan antara dua orang atau lebih di mana pihak yang satu berhak atas sesuatu dan pihak yang lain berkewajiban atas sesuatu. ${ }^{5}$ Definisi "perikatan" menurut doktrin para ahli adalah : "Hubungan hukum dalam bidang harta kekayaan di antara dua orang (atau lebih), di mana pihak yang satu (debitur) wajib

${ }^{4}$ L.M. Friedman, The Legal System, A Social Science Perspective, New York : Russel Sage Faoundation, 1975, hlm. 226. Lihat juga L.M. Friedman, Law and The Behavior Sciences, New York : Bobbs Merill Comp. Inc, 1975, hlm. 179.

5 Purwahid Patrik, Dasar-Dasar Hukum Perikatan, Bandung : Mandar Maju, 1994, hlm 2. melakukan prestasi, dan pihak yang lain (kreditur) berhak atas prestasi itu”. Dari defenisi tersebut, dapat ditarik suatu kseimpulan bahwa, perikatan merupakan hubungan hukum antara dua pihak,dan jadi suatu akibat dari norma-norma hukum. Dalam suatu perikatan/perjanjian, terdapat asas-asas yang melingkupinya. Oleh para pakar hukum kontrak/perjanjian asas-asas tersebut adalah; asas kebebasan berkontrak, asas konsensualisme, asas pacta sun servanda, dan asas itikad baik. ${ }^{6}$

\section{B. Pembahasan}


1. Penyelesaian sengketa

merek melalui forum

arbitrase SIAC, WIPO

Arbitration Centre

dan Badan Arbitrase

Nasional Indonesia

(BANI).

a. Majelis arbiter di

SIAC, $\quad W I P O$

Arbitration Centre, dan BANI

Peraturan prosedur

SIAC (SIAC Rules)

merupakan peraturan

prosedur arbitrase

yang cukup lengkap,

terutama terkait

penentuan kualifikasi

dan kecakapan

seorang arbiter yang

dapat menjadi panel

di SIAC. Peraturan

prosedur arbitrase

WIPO Arbitration
Centre tidak mengatur

secara eksplisit syarat-

syarat yang spesifik

untuk penunjukan

seorang arbiter.

Pengaturan tentang

kualifikasi seperti

pengetahuan,

pengalaman, reputasi,

dan akuntabilitas

seorang arbiter tidak

tercantum dalam

peraturan prosedur

arbitrase $\quad$ WIPO

Arbitration Centre.

Ketentuan tentang

arbiter yang lebih

spesifik dari peraturan

prosedur BANI dan

SIAC dibandingkan

WIPO Arbitration

Rules adalah sebuah

kontradiktif.

Seharusnya, sebagai 
sebuah lembaga yang

diberikan kewenangan

untuk melakukan

penyelesaian sengketa

HKI, WIPO memiliki

peraturan tentang

arbiter yang lebih

tegas terlebih lagi

terkait kualifikasi,

syarat, dan kriteria-

kriteria seorang

arbiter

Pengaturan lain yang

cukup penting di

cantumkan secara

tegas dalam Peraturan

Prosedur BANI, SIAC

Rules dan WIPO

Arbitration Rules

adalah terkait imunitas

seorang arbiter.

Masalah imunitas

seorang arbiter akan

menjadi perdebatan manakala arbiter gagal

dalam menjalankan

tugasnya. Akan

muncul pertanyaan

lanjutan apakah

arbiter

bertanggungjawab

atas kerugian yang

diderita para pihak.

Sejauh ini, pengaturan

dalam Peraturan

Prosedur BANI SIAC

Rules dan WIPO

Arbitration Rules

hanya menyebutkan

adanya penggantian

arbiter jika dinilai

gagal menjalanka

tugasnya dengan baik.

Singapura dan

Indonesia perlu

mengakomodir hal

imunitas arbiter ini

dalam peraturan 
prosedur arbitrase di

SIAC dan BANI dan

menyesuaikannya

dengan sistem hukum

negara masing-

masing.

b. Pemeriksaan

Perkara (hearing)

Kewenangan

ketua majelis arbitrase

dalam menetapkan

aturan-aturan

prosedural dapat

dilihat di SIAC Rules, WIPO Arbitration

Rules dan Peraturan

prosedur abitrase

BANI. Dalam Article

38

(c) WIPO

Arbitration Rules, disebutkan bahwa : “.....at the request of a party or on its own motion, extend in expceptional cases a period of time fixed by these Rules, by itself or agreed to by parties. In urgent cases, such an extension may be granted by the presiding arbitrator alone." SIAC Rules menentukan kewenangan ketua majelis arbitrase tersebut dalam pengaturan yang sedikit berbeda. Menurut SIAC Rules, seorang ketua majelis arbitrase dapat membuat sendiri aturan terkait hal-hal prosedural, namun tetap terbuka untuk 
direvisi/diubah oleh

menetapkan aturan-

majelis arbitrase. ${ }^{7}$

aturan yang sifatnya

Peraturan

prosedural dalam

Prosedur Arbitrase

proses arbitrase. Ide

BANI menyebutkan

dasarnya pemberian

dengan tegas bahwa

kewenangan ini

ketua majelis dapat

menetapkan sendiri

aturan bersifat

dianggap sebagai

prosedural. ${ }^{8}$ Dengan

seorang yang

demikian $\quad W I P O$

akuntabel dan

Arbitration Rules,

SIAC Rules, maupun

Peraturan Prosedur

Arbitrase BANI

sejatinya memberikan

ruang bagi ketua

majelis arbitrase untuk

7 Lihat SIAC Rules, Article 16.5 : " $a$ presiding arbitrator may make procedural rulings alone, subject to revision by the tribunal"

8 Lihat Pasal 28 Peraturan Prosedur Arbitrase BANI, dalam pasal tersebut disebutkan bahwa : Untuk hal-hal yang bersifat prosedural, apabila tidak terdapat kesepakatan mayoritas, dan apabila Majelis menguasakan untuk hal tersebut, Ketua Majelis dapat memutuskan atas pertimbangan sendiri.

adalah bahwa seorang

ketua majelis arbitrase

profesional, sehingga

mampu menjalankan

proses arbitrase

bersama majelis

arbitrase dengan

pertimbangan-

pertimbangan teoritis,

praktis, maupun

efisiensi waktu dan

biaya yang muncul.

\section{SIAC Rules}

memberikan jaminan

kerahasiaan dalam 


\begin{tabular}{|c|c|}
\hline proses pemeriksaan & Senada \\
\hline meliputi & peraturan \\
\hline pertemuan-pertemuan & lainnya, Peraturan \\
\hline yang dilakukan dalam & Prosedur \\
\hline rangka/proses & BANI \\
\hline pemeriksaan, & menyebutkan bahwa \\
\hline pemeriksaan saksi dan & Seluruh persidangan \\
\hline rekaman- & dilakukan tertutup \\
\hline rekaman, transkrip & untuk umum, dan \\
\hline dokumen- & segala hal yang \\
\hline dokumen & berkaitan dengan pe- \\
\hline dipergunakan dalam & nunjukan \\
\hline pemeriksaan. $^{9}$ & termasuk dokumen, \\
\hline Sementara itu di & laporan/catatan sidang \\
\hline dalam & -sidang, keterangan- \\
\hline Arbitration & keterangan saksi dan \\
\hline secara & putusan-putusan, \\
\hline disebutkan & dijaga \\
\hline semua hal yang terkait & kerahasiaannya \\
\hline rangkaian & diantara para pihak, \\
\hline pemeriksaan harus & para arbiter dan \\
\hline rahasia. $^{10}$ & BANI, kecuali oleh \\
\hline & peraturan perundang- \\
\hline
\end{tabular}

10 Lihat WIPO Arbitration Rules, Article 53.

(c) 
tidak diperlukan atau

disetujui oleh semua

pihak

yang

bersengketa. $^{11}$

c. Putusan Abitrase,

Penerapan Prinsip

Res Judicata, dan

Kerahasiaan

Putusan

Kerahasiaan suatu

putusan arbitrase

wajib dijaga oleh

majelis arbitrase dan

para pihak. SIAC

Arbitration Rules

secara tegas

menyebutkan bahwa

majelis arbitrase dan

para pihak menjaga

kerahasiaan terhadap

segala hal yang

berkaitan dengan

11 Lihat Peraturan Prosedur BANi, Pasal 13 ayat (2) proses arbitrase dan

putusan arbitrase itu

sendiri. $^{12}$

Kerahasiaan

putusan arbitrase pada

prinsipnya harus tetap

dijaga dan tidak boleh

dipublikasikan kecuali

atas kesepakatan para

pihak. ${ }^{13}$ Para pihak

dapat mengatur

kerahasiaan dari

proses dan putusan

arbitrase dalam

perjanjian arbitrase

yang mereka buat. Hal

ini akan sangat

berguna apabila

arbitrase yang

digunakan adalah $a d$

hoc atau peraturan

12 SIAC Rules, Article 35.1

13 Lihat juga LCIA Rules, Article 30, ICDR Rules, Article 34, UNCITRAL Rules, Article 34 ayat (5). 


\begin{tabular}{|c|c|}
\hline \multirow{2}{*}{$\begin{array}{l}\text { prosedur arbitrase } \\
\text { yang ada di lembaga }\end{array}$} & majelis arbitrase, para \\
\hline & pihak dan \\
\hline arbitrase yang dipilih & dalam waktu 30 (tiga \\
\hline para pihak tidak & puluh) hari sejak \\
\hline mengakomodasi/mem & putusan diterima oleh \\
\hline berikan perlindungan & pihak. \\
\hline yang cukup atas & permohonan koreksi \\
\hline kerahasiaan putusan & diterima, maka majelis \\
\hline arbitrase & arbitrase \\
\hline dihasilkan. & membuat \\
\hline d. Koreksi & dalam waktu 30 (tiga \\
\hline Interpretasi & puluh) hari sejak \\
\hline Putusan Arbitrase & permohonan diterima \\
\hline & Majelis \\
\hline WIPO Arbitration & Arbitrase. \\
\hline Rules menyebutkan & berbeda dengan SIAC \\
\hline bahwa para pihak & Rules, koreksi ini \\
\hline dapat mengajukan & harus dibuat terpisah \\
\hline permohonan koreksi & dengan putusan, dan \\
\hline kesalahan & ditandatangani \\
\hline penulisan dan/atau & arbitrase. \\
\hline jumlah dari suatu & Namun, koreksi atas \\
\hline arbitrase. & putusan ini harus tetap \\
\hline Permohonan tersebut & dianggap \\
\hline disampaikan kepada & \\
\hline
\end{tabular}




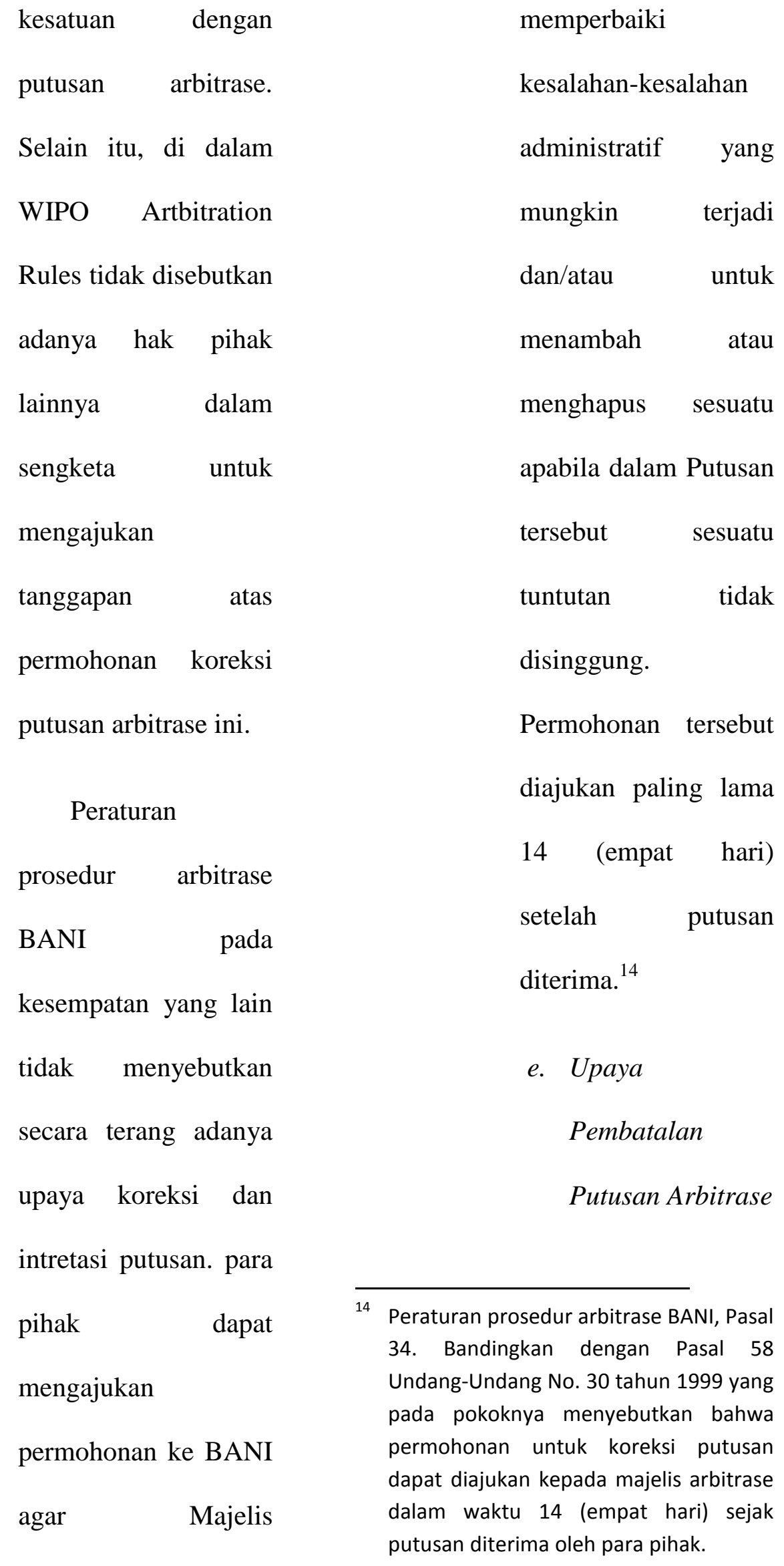


Perihal

pembatalan putusan

arbitrase memang

tidak ditemukan

dalam SIAC Rules,

WIPO Arbitration

Rules, dan Peraturan

Prosedur Arbitrase

BANI. Kontrasnya,

upaya pembatalan ini

diakomodir dalam

Undang-Undang No.

$30 \quad$ Tahun 1999

tentang Arbitrase dan

Alternatif

Penyelesaian

Sengketa. Dalam

Pasal 70 undang-

undang ini jelas

disebutkan bahwa

adanya hak para pihak

yang dilegitimasi oleh

undang-undang untuk

mengajukan pembatalan putusan

arbitrase yang

didasarkan atas

alasan-alasan adanya

pemalsuan dokumen-

dokumen atau surat-

surat pada saat

pemeriksaan arbitrase

dilakukan, adanya

dokumen yang

disembunyikan para

pihak, putusan diambil

dari hasil tipu

muslihat yang

dilakukan oleh salah

satu pihak yang

bersengketa.

2. Pelaksanaan putusan

arbitrase SIAC, WIPO

Arbitration Centre dan

BANI ditinjau dari

Undang-Undang No. 30

Tahun 1999 tentang 
pelaksanaan dari putusan arbitrase luar negeri

a. Prinsip pengakuan dan pelaksanaan putusan arbitrase asing ditinjau dari New York Convention 1958

Penyampingan putusan arbitrase asing juga dimungkinkan menurut New York Convention $\quad 1958$. Penyampingan putusan arbitrase asing ini didasarkan jurisdiksi dan ketentuan negara masingmasing anggota. Article $V$ New York Convention 1958 menyebutkan bahwa dasar yang dapat digunakan untuk menolak permohonan $\operatorname{adalah}^{15}$ :

a) apabila para pihak menurut perjanjian arbitrase mereka dan hukum yang berlaku untuk mereka sebenarnya tidak mempunyai wewenang untuk melangsungkannya.

b) Pihak terhadap siapa telah dimintakan pelaksanaan putusan arbitrase ini tidak diberitahukan dengan pemberitahuan yang wajar tentang diangkatnya arbitrator atau tentang adanya perkara arbitrase ini, hingga ia tidak dapat mengajukan pembelaannya. Di sini kembali lagi,

15 Sudargo Gautama, Op. Cit, hlm. 80. 


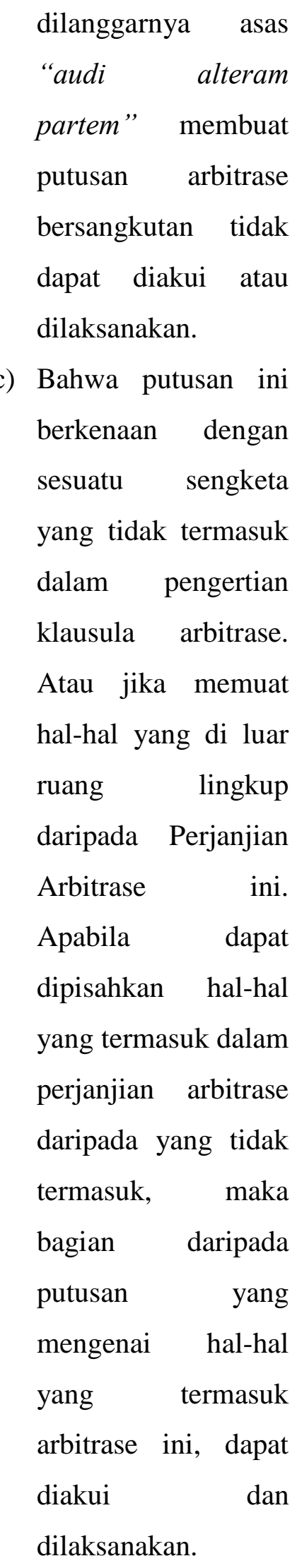

d) Atau apabila komposisi daripada majelis arbitrase atau proses arbitrase tidak sesuai dengan apa yang telah disepakati oleh para pihak. Jika tidak ada perjanjian semacam ini, acaranya tidak sejalan dengan hukum dari negara di mana arbitrase ini telah berlangsung.

e) Apabila putusan ini belum mengikat para pihak atau telah dikesampingkan atau telah ditunda oleh suatu instansi yang berwenang di negara mana putusan ini telah dibuat.

f) Di samping itu menurut Article $V$. (2) New York Convention 1958 pengakuan dan pelaksanaan putusan luar negeri ini dapat juga ditolak apabila menurut instansi 


$$
\begin{array}{lr}
\text { yang berwenang } \\
\text { dalam negara di } \\
\text { mana hendak diakui } \\
\text { atau dilaksanakan } \\
\text { putusan ini, }
\end{array}
$$$$
\text { berpendapat bahwa : }
$$

1) Pokok daripada sengketa tidak dapat dibawa kepada arbitrase, atau

2) Pengakuan atau pelaksanaan putusan

arbitrase bertentangan dengan ketertiban umum pada negara yang dimintakan pelaksanaanya.

b. Syarat-syarat eksekusi putusan arbitrase ditinjau dari UndangUndang No. 30 Tahun 1999 tentang Arbitrase dan
Penyelesaian

Sengketa

Adapun syarat-syarat putusan arbitrase internasional untuk dapat diakui serta dapat dilaksanakan di wilayah hukum Republik Indonesia adalah sebagai berikut ${ }^{16}$

a) Putusan Arbitrase Internasional dijatuhkan oleh arbiter atau majelis arbitrase di suatu negara yang dengan negara Indonesia terkait pada perjanjian, baik secara bilateral maupun multilateral, mengenai pengakuan dan pelaksanaan Putusan Arbitrasi

Internasional.

b) Putusan Arbitrase Internasional sebagaimana dalam huruf a terbatas pada Alternatif
16 Pasal 66 Undang-Undang No. 30 Tahun 1999 


$\begin{array}{llr}\text { putusan yang menurut } & \text { dalam } & \text { sengketa, } \\ \text { ketentuan hukum } & \text { hanya } & \text { dapat } \\ \text { Indonesia termasuk } & \text { dilaksankaan } & \text { setelah } \\ \text { dalam ruang lingkup } & \text { memperoleh } & \\ \text { hukum perdagangan. } & \text { eksekuatur } & \text { dari } \\ \text { Putusan Arbitrase } & \text { Mahkamah Agung } \\ \text { Internasional } & \text { Republik Indonesia } \\ \text { sebagaimana } & \text { yang selanjutnya } \\ \text { dimaksud dalam huruf } & \text { dilimpahkan kepada } \\ \text { a hanya dapat } & \text { Pengadilan Negeri } \\ \text { dilaksanakan di } & \text { Jakarta Pusat. }\end{array}$

Indonesia terbatas

\section{Kesimpulan dan Saran}

pada putusan yang

tidak bertentangan

Peraturan prosedur arbitrase

dengan ketertiban

umum.

d) Putusan Arbitrase

Internasional dapat

dilaksanakan di

Indonesia setelah

memperoleh

eksekuatur dari Ketua

Pengadilan Negeri

Jakarta Pusat; dan

e) Putusan Arbitrase

Internasional

sebagaimana

dimaksud dalam huruf

a yang menyangkut

Negara Republik

Indonesia sebagai

salah satu pihak

SIAC lebih lengkap dan jelas.

Namun hal ini tidak berarti bahwa

Peraturan prosedur BANI dan WIPO

Arbitration Centre tidak cukup baik

untuk dijadikan acuan dalam proses

penyelesaian sengketa melalui

arbitrase. Oleh karena itu, jika

terdapat sengketa merek, lembaga

arbitrase yang menjadi pilihan

utama adalah SIAC. Adanya

kemungkinan penolakan putusan

arbitrase internasional dengan alasan

ketertiban umum pada dasarnya

merupakan langkah negara 
Indonesia untuk mempertahankan kepentingan publik (nasional).

Namun demikian, perihal penilaian ketertiban umum oleh Ketua Pengadilan Negeri Jakarta Pusat memang harus benar-benar mendalam dan komprehensif dengan memperhatikan segala aspek sosial atas pelaksanaan putusan arbitrase internasional.

Ketentuan tentang upaya pembatalan dalam Undang-Undang No. 30 tahun 1999 tentang Arbitrase dan Alternatif Penyelesaian Sengketa sebaiknya perlu diharmonisasikan dengan peraturan prosedur arbitrase BANI. Hal ini sebagai upaya menjaga konsistensi asas dan prinsipprinsip dalam perjanjian dan ketentuan dalam hukum positif di Indonesia. Para pihak dapat menghindari upaya pembatalan putusan arbitrase, apabila masingmasing pihak mau menjalankan proses penyelesaian arbitrase dengan itikad baik. Hal ini mengingat, dasar adanya pembatalan sangat berkaitan dengan hal-hal yang menunjukkan itikad tidak baik dari salah satu pihak.

\section{Daftar Pustaka}

Adolf, Huala. Hukum Penyelesaian Sengketa Internasional, Jakarta : Sinar Grafika, 2004.

Colston, Catherine. Principles of Intellectual Property Rights. London-Sydney : Cavendish Publishing Ltd.,1999.

Ditjen HKI, Buku Panduan Hak Kekayaan Intelektual,

Direktorat Jenderal Hak Kekayaan Intelektual Kementerian Hukum dan HAM RI, 2011.

Edenborough, Michael. Intellectual Property Law, London : Cavendish Publishing Limited, 1995.

Elkouri, Frank dan Edna Elkouri, How Arbitration Works", Eashington D.C., 1974 
Gautama, Sudargo. Aneka Hukum

Arbitrase (Ke-arah Hukum

Arbitrase Indonesia yang

Baru), Bandung : Citra Aditya

Bakti, 1996.

\section{Arbitre Dagang}

Internasional, Bandung :

Almuni, 1979.

--------------. Indonesia dan

Arbitrase Internasional,

Bandung : Alumni, 1986.

Harahap, Yahya. Arbitrase (Edisi

Kedua), Jakarta : Sinar

Grafika, 2003.

Hartono,Darminto. Economic

Analysis of Law atas Putusan

PKPU Tetap, Jakarta :

Lembaga Studi Hukum dan

Ekonomi Fakultas Hukum

Universitas Indonesia, 2009.

Lew, Julian D.M. Appplicable Law

in International Commercial

Arbitration.

Oceana

Publication Inc. 1978

Merrils, J.G. International Dispute

Settlement, London : Sweet \&

Maxwell, 1994.

Moleong, Lexy. Metode Peneltian

Kualitatif (Edisi Revisi),

Bandung : Remaja Rosdakarya, 2005.
Morrissey, Joseph F Jack dan M.

Graves, International Sales

Law and Arbitration

(Problems, Cases, adn

Commentary), Netherlands :

Wolters Kluwer Law Business, 2008.

Moses, Margaret L., The Principles and Practice of International Commercial Arbitration (Second Edition), New York : Cambridge University Press, 2012.

Rajagukguk, Erman. Butir-Butir Hukum Ekonomi, Jakarta : Lembaga Studi Hukum dan Ekonomi Fakultas Hukum UI, 2011.

Saidin, OK. Aspek Hukum Hak Kekayaan Intelektual, Jakarta : PT Raja Grafindo Persada, 1995.

Sembiring, Jimmy Joses. Cara Menyelesaikan Sengketa di Luar Pengadilan (Negosiasi, Mediasi, Konsiliasi, Arbitrase), Jakarta : Visimedia, 2011.

Soekanto, Soerjono dan Sri Pamudji, Penelitian Hukum Normatif, Jakarta : CV. Rajawali, 1985. 
Subekti, Arbitrase Perdagangan,

Bandung : Angkasa Offset, 1981

Sulistiyono, Adi. Eksistensi dan Penyelesaian Sengketa HaKI (Hak Kekayaan Intelektual), Surakarta : Sebelas Maret University Press, 2008.

Sutedi, Adrian. Hak Kekayaan Intelektual, Jakarta : Sinar Grafika, 2009.

Wignjosoebroto, Soetandyo. HUKUM (Paradigma, Metode, dan Dinamika Masalahnya), Jakarta : ELSAM-HUMA, 2002. 